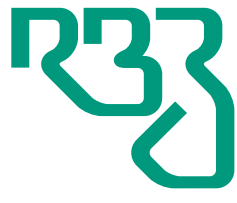

Revista Brasileira de Zootecnia

Brazilian Journal of Animal Science ISSN 1806-9290 www.rbz.org.br

\section{Organic minerals with different chemical characteristics in diets for Hy-Line White laying hens: performance, biometry of digestive organs, and bone quality}

\author{
Maria Rogervânia Silva de Farias ${ }^{1^{*}}$ (D), Silvana Cavalcante Bastos-Leite ${ }^{1}$ (D), \\ Constância Pontes Moura ${ }^{1}$ (iD), Adailton Camêlo Costa $^{1}$ (iD), Cláudia Goulart \\ ${\text { de } \text { Abreu}^{1} \text { (iD, Thaís Lucas de Sena }}^{1}$ iD \\ ${ }^{1}$ Universidade Estadual Vale do Acaraú, Centro de Ciências Agrárias e Biológicas, Sobral, CE, \\ Brasil.
}

\begin{abstract}
Two trials were carried out to evaluate the effect of groups of organic minerals with different chemical characteristics on the performance, egg quality, biometry of digestive organs, and bone quality of laying hens in the first and second laying cycles. In the first cycle, 180 layers at 72 weeks were used in a completely randomized design (CRD) with four treatments and five replicates with nine birds each. In the second cycle, 216 layers at 94 weeks of age were used in a CRD with four treatments and six replicates with nine birds each. Birds were fed the following diets: treatment 1 - basal diet (inorganic minerals); treatment 2 - basal diet + amino acid chelated minerals $(\mathrm{Cu}, \mathrm{Fe}, \mathrm{Mn}$, and $\mathrm{Zn})+$ selenium yeast; treatment 3 - basal diet + mineral-amino acid complex (Mn, $\mathrm{Zn}$, and $\mathrm{Cu}$ ); and treatment 4 - basal diet + metal chelate $(\mathrm{Mn}, \mathrm{Zn}$, and $\mathrm{Cu})+$ methionine hydroxy analogue. The following performance variables were evaluated: feed intake (g/bird/day), egg production (\%), egg weight (g), egg mass (g/bird/day), conversion per mass $(\mathrm{kg} / \mathrm{kg})$, and conversion per dozen eggs $(\mathrm{kg} / \mathrm{dz})$. In the egg, the percentages of albumen, yolk, and shell; eggshell thickness $(\mathrm{mm})$; and specific gravity $\left(\mathrm{g} / \mathrm{cm}^{3}\right)$ were determined. The relative weights $(\%)$ of the proventriculus, gizzard, liver, pancreas, and intestines were also measured. Lastly, in the tibiae, the weight $(\mathrm{g})$, length $(\mathrm{mm})$, resistance $\left(\mathrm{kgf} / \mathrm{cm}^{2}\right)$, deformity $(\mathrm{mm})$, Seedor index $(\mathrm{mg} / \mathrm{mm})$, and mineral matter content $(\mathrm{g} / \mathrm{kg})$ were measured. The variables were not influenced by the groups of organic minerals used. Groups of organic minerals with different chemical characteristics can be used in layer diets without affecting their performance, egg quality, digestive organs, or bone quality.
\end{abstract}

Keywords: bone resistance, chelated amino acid, laying, Seedor index

\title{
Introduction
}

The commercial-poultry production system in Brazil hit the mark of 788,260,000 dozen eggs in the first trimester of 2017, which represents an increase of 31,060,000 dozens when compared with the same period in the previous year (IBGE, 2017). These figures prove the visible growth in the laying-poultry sector in the country. Such growth, in turn, is a result of the combined action of factors influencing production, one of which is the nutritional management, given that nutrition is one of the foundations of animal production (Alves et al., 2015).

For an animal to present a good nutritional status, it must receive adequate quantities of all nutrients essential to its organism, among which are minerals. For many years, minerals originating from inorganic sources have been used to meet the mineral requirements of birds; however, their bioavailability is 
low, which results in losses during the absorption process that compromise the animal performance (Carvalho et al., 2016).

A strategy that has been adopted to elevate the bioavailability of these minerals and thus reduce losses during the absorption process is the use of minerals from organic sources replacing or supplementing conventional sources, with a view to increasing production efficiency (Pacheco et al., 2010).

Organic minerals are defined as metal ions chemically linked to an organic molecule. These are classified by the Association of American Feed Control Officials (AAFCO, 2000) into the following groups: metalamino acid chelates, metal-amino acid complex, specific metal-amino acid complex, metal proteinate, and polysaccharide metal complex.

There are many types of commercially available products containing the groups of organic minerals described above, and each carries a different proposal, with a higher or lower bioavailability of the involved minerals (Saleh et al., 2018). In this way, questions arise as to the molecule to be chosen as a ligand of the mineral used in the product. The efficiency of each of group of these may, however, vary according to how it is produced.

In view of this scenario, the present study tested the hypothesis that groups of organic minerals with different chemical characteristics influence the performance, egg quality, biometry of digestive organs, and bone quality of white-egg laying hens in their first and second laying cycles.

\section{Material and Methods}

The project was approved by the local ethics committee (case no. 001.05.016.UVA.504.03). The two trials were carried out in Sobral, CE, Brazil (0341'10" S latitude, 40²0'59" W longitude, and $69 \mathrm{~m}$ asl).

Birds were housed in galvanized-wire cages measuring $30 \times 45 \times 45 \mathrm{~cm}$, equipped with a frontal metal trough feeder and a nipple drinker per cage. All birds received the same daily management during the evaluated period, with water available ad libitum. A lighting program of $16 \mathrm{~h}$ per day was adopted, consisting of $12 \mathrm{~h}$ of natural plus $4 \mathrm{~h}$ of artificial illumination.

Before the start of the experiments, birds were weighed and selected to generate experimental plots with uniform body weights and egg production, following recommendations proposed by Sakomura and Rostagno (2007).

In the first trial, $180 \mathrm{Hy}$-Line White laying hens at 72 weeks of age, in their first laying cycle, weighing $1.673 \pm 0.109 \mathrm{~kg}$, were used in a completely randomized design with four treatments and five replicates with nine birds each. The experimental period was 84 days, divided into three 28-day sub-periods.

The experimental diets were isonutritive and isocaloric (Table 1), formulated according to the nutritional requirements suggested by the Hy-Line White manual (Hy-Line do Brasil, 2016), and the composition of ingredients used in the formulation followed the recommendation of Rostagno et al. (2011). The following experimental diets were tested: Treatment 1 - basal diet (corn, soybean meal, a calcium and phosphorus source, a vitamin premix, vegetable oil, and common salt containing only inorganic minerals); Treatment 2 - basal diet + amino acid chelated minerals ( $\mathrm{Cu}, 5 \mathrm{ppm}$; Fe, 35 ppm; $\mathrm{Mn}, 40 \mathrm{ppm}$; and Zn, $55 \mathrm{ppm}$ ) + selenium yeast (16 ppm); Treatment 3 - basal diet + mineral-amino acid complex (Mn, 40 ppm; $\mathrm{Zn}, 40 \mathrm{ppm}$; and $\mathrm{Cu}, 7 \mathrm{ppm}$ ); and Treatment 4 - basal diet + metal chelate (Mn, 40 ppm; Zn, 40 ppm; and Cu, 8 ppm)-methionine hydroxy analogue [MHA]).

Egg production was recorded daily until the end of each 28-day period, when these data, together with those pertaining to feed intake, were used to calculate the performance variables. The following variables were assessed: feed intake (g/bird/day), egg production (\%), egg weight (g), egg mass (g/bird/day), conversion per egg mass $(\mathrm{kg} / \mathrm{kg})$, and conversion per dozen eggs $(\mathrm{kg} / \mathrm{dz})$.

At the end of each period, the following egg quality parameters were also evaluated: percentages of albumen, yolk, and shell; eggshell thickness ( $\mathrm{mm})$; and specific gravity $\left(\mathrm{g} / \mathrm{cm}^{3}\right)$. For these measurements, four eggs were selected per replicate, two of which for the determination of specific gravity and the other two for the remaining quality analyses.

R. Bras. Zootec., 48:e20170329, 2019 
The second trial involved 216 Hy-Line White layers at 94 weeks of age, in the second laying cycle, weighing $1.689 \pm 0.100 \mathrm{~kg}$, for 105 days that were divided into five 21-day periods. A completely randomized design was adopted with four treatments and six replicates with nine birds each. Experimental diets were similar to those of the first trial, with the same nutritional levels except for calcium, which was $4 \%$ in the second trial.

After every 21-day period, the following egg quality parameters were assessed: percentages of albumen, yolk, and shell; eggshell thickness $(\mathrm{mm})$; and specific gravity $\left(\mathrm{g} / \mathrm{cm}^{3}\right)$. For these measurements, four eggs were selected per replicate, two of which for the determination of specific gravity and the other two for the remaining quality analyses.

At the end of 105 days, 20 birds per treatment were chosen at random and identified. These were euthanized by the cervical-dislocation method (following Normative Resolution no. 13/2013 - CONCEA, 2013) and taken to the laboratory, where they were weighed individually and had their organs removed and emptied in a necropsy for biometric evaluations of the gizzard, liver, pancreas, and intestines, using a 0.01-g precision scale (adapted from Braz et al., 2011). All weight data were expressed as a percentage of body weight.

Table 1 - Calculated nutritional composition of the experimental diet (as-fed basis; g/kg)

\begin{tabular}{|c|c|c|c|c|}
\hline Ingredient (g/kg) & Inorganic & $\begin{array}{l}\text { Amino acid } \\
\text { chelate }\end{array}$ & $\begin{array}{l}\text { Amino acid } \\
\text { complex }\end{array}$ & $\begin{array}{c}\text { Metal } \\
\text { chelate-MHA }\end{array}$ \\
\hline Corn grain & 607.00 & 607.00 & 607.00 & 607.00 \\
\hline Soybean meal & 219.50 & 219.50 & 219.50 & 219.50 \\
\hline Limestone & 84.00 & 84.00 & 84.00 & 84.00 \\
\hline Meat meal & 54.80 & 54.80 & 54.80 & 54.80 \\
\hline Vitamin-mineral supplement ${ }^{1}$ & 4.00 & 4.00 & 4.00 & 4.00 \\
\hline Common salt & 2.72 & 2.72 & 2.72 & 2.72 \\
\hline Soybean oil & 25.70 & 25.70 & 25.70 & 25.70 \\
\hline DL-methionine & 1.22 & 1.22 & 1.22 & 1.22 \\
\hline Inert & 1.00 & 0 & 0 & 0.39 \\
\hline Amino acid chelates + selenium yeast & 0 & 1.00 & 0 & 0 \\
\hline Amino acid complex $(\mathrm{Mn}+\mathrm{Zn}+\mathrm{Cu})$ & 0 & 0 & 1.00 & 0 \\
\hline Zn metal chelate-MHA & 0 & 0 & 0 & 0.25 \\
\hline Mn metal chelate-MHA & 0 & 0 & 0 & 0.31 \\
\hline $\mathrm{Cu}$ metal chelate-MHA & 0 & 0 & 0 & 0.05 \\
\hline Metabolizable energy (kcal/kg) & 2900 & 2900 & 2900 & 2900 \\
\hline Crude protein (g/kg) & 175.00 & 175.00 & 175.00 & 175.00 \\
\hline Calcium (g/kg) & 41.00 & 41.00 & 41.00 & 41.00 \\
\hline Available phosphorus (g/kg) & 4.30 & 4.30 & 4.30 & 4.30 \\
\hline Sodium (g/kg) & 1.80 & 1.80 & 1.80 & 1.80 \\
\hline Digestible met + cys (g/kg) & 6.60 & 6.60 & 6.60 & 6.60 \\
\hline Digestible methionine $(\mathrm{g} / \mathrm{kg})$ & 4.16 & 4.16 & 4.16 & 4.16 \\
\hline Digestible lysine (g/kg) & 7.64 & 7.64 & 7.64 & 7.64 \\
\hline Digestible threonine (g/kg) & 5.60 & 5.60 & 5.60 & 5.60 \\
\hline Digestible tryptophan (g/kg) & 1.69 & 1.69 & 1.69 & 1.69 \\
\hline
\end{tabular}

MHA - methionine hydroxy analogue.

${ }^{1}$ Provides per kg of product: iron (min), 10.00 g; copper (min), 2,500.00 mg; zinc (min), 20.00 g; manganese (min), 20.00 g; iodine (min), $208.00 \mathrm{mg}$; selenium (min), $75.15 \mathrm{mg}$; vitamin A (min), 2,000,000.00 IU; vitamin D3 (min), 625,000.00 IU; vitamin E (min), 3,000.00; vitamin K3 (min), $395.92 \mathrm{mg}$; folic acid (min), $74.25 \mathrm{mg}$; choline (min), $100.00 \mathrm{~g}$; niacin (min), 5,025.74 mg; pantothenic acid (min), 1,805.16 mg; vitamin B1 (min), 250,09 mg; vitamin B2 (min), 1,000.00 mg; vitamin B6 (min), $250.1 \mathrm{mcg}$; vitamin B12 (min), 2,400.00; methionine (min), $125.00 \mathrm{~g}$; colistin (min) 1,750.00 mg. 
Right and left tibiae were also removed to analyze the following bone characteristics: weight (g), length $(\mathrm{mm})$, resistance $\left(\mathrm{kgf} / \mathrm{cm}^{2}\right)$, deformity $(\mathrm{mm})$, Seedor index $(\mathrm{mg} / \mathrm{mm})$, and mineral matter $(\mathrm{g} / \mathrm{kg})$. Bone length was measured using a digital caliper, and its weight was obtained on an electronic scale with $0.01-\mathrm{g}$ precision. Bone density was evaluated based on the Seedor index, which was calculated by dividing the weight $(\mathrm{mg})$ by the length ( $\mathrm{mm}$ ) of the evaluated bone (Seedor et al., 1991).

Analyses of bone resistance and deformity were performed using a mechanical press, where the left tibiae were placed in the horizontal position, and then a compression force was applied to the center of each one of them. The maximum force applied onto the bone until it broke was considered the breaking strength $\left(\mathrm{kgf} / \mathrm{cm}^{2}\right)$, which was measured using a digital strain gauge. Deformity $(\mathrm{mm})$ was measured using an analogical stain gauge until the moment of bone rupture.

After deboning, the right tibiae were weighed and dried in a forced-air oven at $105^{\circ} \mathrm{C}$ for $72 \mathrm{~h}$ (Abudabos, 2012). Next, they were weighed and crushed with a mortar and pestle. Crushed samples were then identified for the determination of the mineral matter, following the methodology described by Silva and Queiroz (2002).

In the two experiments, the statistical procedures were applied using the SAS statistical software (Statistical Analysis System, version 8). The average data of the period were subjected to an analysis of variance, and means were compared by the SNK test at the $5 \%$ probability level.

Variables were analyzed according to the following mathematical model:

$$
Y i j=\mu+\beta i+\varepsilon i j
$$

in which Yij $=$ observation $j$ of experimental unit subjected to treatments $i, \mu=$ general constant, $\beta i=$ effects of rations with organic minerals with different chemical characteristics, and $\varepsilon i j=$ random error associated to each observation.

\section{Results}

In the first trial, regardless of the chemical characteristics of the groups of organic minerals used, no significant differences were observed $(\mathrm{P}>0.05)$ for any of the performance or egg quality variables (Tables 2 and 3). The same result was found for the second trial (Table 4).

In the biometric analysis of the digestive organs, no significant differences were observed $(\mathrm{P}>0.05)$ for the relative weights of gizzard, liver, pancreas, proventriculus, and intestines (Table 5).

Irrespective of the chemical characteristics of the groups of organic minerals used, no significant differences were observed $(P>0.05)$ for weight, length, Seedor index, resistance, deformity, or mineral matter content of the tibiae (Table 6).

Table 2 - Mean values for performance traits of Hy-Line White layers fed diets containing groups of minerals with different chemical characteristics, in the period of 72 to 84 weeks of age

\begin{tabular}{lcccccc}
\hline Supplement $^{1}$ & $\begin{array}{c}\text { Intake } \\
\text { (g/bird/day) }\end{array}$ & $\begin{array}{c}\text { Production } \\
(\%)\end{array}$ & $\begin{array}{c}\text { Egg weight } \\
(\mathrm{g})\end{array}$ & $\begin{array}{c}\text { Egg mass } \\
(\mathrm{g} / \mathrm{bird} / \mathrm{day})\end{array}$ & $\begin{array}{c}\mathrm{CM} \\
(\mathrm{kg} / \mathrm{kg})\end{array}$ & $\begin{array}{c}\mathrm{CDZ} \\
(\mathrm{kg} / \mathrm{dz})\end{array}$ \\
\hline 1 & 89.73 & 62.72 & 65.47 & 41.06 & 2.204 & 1.732 \\
2 & 93.58 & 62.92 & 65.22 & 41.08 & 2.291 & 1.792 \\
3 & 92.93 & 63.93 & 65.25 & 41.71 & 2.245 & 1.758 \\
4 & 91.54 & 64.91 & 66.13 & 42.55 & 2.157 & 1.696 \\
Mean & 91.95 & 63.62 & 65.53 & 41.59 & 2.123 & 1.744 \\
CV (\%) & 5.44 & 7.61 & 1.89 & 7.90 & 7.78 & 8.25 \\
P-value & 0.6347 & 0.8838 & 0.9696 & 0.8753 & 0.6585 & 0.7517 \\
\hline
\end{tabular}

$\mathrm{CM}$ - conversion per egg mass; CDZ - conversion per dozen eggs; CV - coefficient of variation.

${ }_{1}$ Supplement 1 - inorganic minerals; Supplement 2 - inorganic minerals + amino acid chelated minerals + selenium yeast; Supplement 3 - inorganic minerals + mineral-amino acid complex $(\mathrm{Mn}+\mathrm{Zn}+\mathrm{Cu})$; Supplement 4 - inorganic minerals + metal chelate $(\mathrm{Mn}+\mathrm{Zn}+\mathrm{Cu})$-methionine hydroxy analogue. 


\section{Discussion}

With respect to performance (Table 2) - because the birds used in this experiment were at an advanced age and thus outside of their production peak, when the requirements and nutritional challenges are much higher - the inorganic premix used was sufficient to optimize their production and, consequently, the effect of organic supplementations was not evidenced. The obtained results confirm others found

Table 3 - Mean values for measurements of eggs from Hy-Line White layers fed diets containing groups of minerals with different chemical characteristics, in the period of 72 to 84 weeks of age

\begin{tabular}{lccccc}
\hline Supplement $^{1}$ & Albumen (\%) & Yolk (\%) & Shell (\%) & ST (mm) & SG (g/cm $)^{3}$ \\
\hline 1 & 60.02 & 28.00 & 8.49 & 0.342 & 1.084 \\
2 & 59.77 & 28.02 & 8.82 & 0.358 & 1.085 \\
3 & 59.57 & 28.11 & 8.49 & 0.355 & 1.082 \\
4 & 60.28 & 27.60 & 8.59 & 0.357 & 1.084 \\
Mean & 59.91 & 27.93 & 8.60 & 0.353 & 1.084 \\
CV (\%) & 1.38 & 2.62 & 3.21 & 3.49 & 0.20 \\
P-value & 0.5765 & 0.7061 & 0.2379 & 0.1933 & 0.2618 \\
\hline
\end{tabular}

ST - eggshell thickness; SG - specific gravity; CV - coefficient of variation.

${ }^{1}$ Supplement 1 - inorganic minerals; Supplement 2 - inorganic minerals + amino acid chelated minerals + selenium yeast; Supplement 3 - inorganic minerals + mineral-amino acid complex $(M n+Z n+C u)$; Supplement 4 - inorganic minerals + metal chelate $(\mathrm{Mn}+\mathrm{Zn}+\mathrm{Cu})$-methionine hydroxy analogue.

Table 4 - Percentages of albumen, yolk, and shell, eggshell thickness (ST), and specific gravity (SG) of Hy-Line White layers fed diets containing groups of minerals with different chemical characteristics, in the period of 94 to 109 weeks of age

\begin{tabular}{lccccc}
\hline Supplement $^{1}$ & Albumen (\%) & Yolk (\%) & Shell (\%) & ST (mm) & SG $\left(\mathrm{g} / \mathrm{cm}^{3}\right)$ \\
\hline 1 & 61.23 & 27.92 & 8.36 & 0.344 & 1.082 \\
2 & 60.42 & 27.79 & 8.51 & 0.348 & 1.082 \\
3 & 59.93 & 27.81 & 8.58 & 0.349 & 1.083 \\
4 & 60.78 & 27.82 & 8.40 & 0.350 & 1.081 \\
Mean & 60.59 & 27.84 & 8.46 & 0.348 & 1.082 \\
CV(\%) & 1.94 & 3.04 & 3.00 & 3.53 & 0.19 \\
P-value & 0.3003 & 0.9958 & 0.4608 & 0.8606 & 0.2007 \\
\hline
\end{tabular}

ST - eggshell thickness; SG - specific gravity; CV - coefficient of variation.

${ }^{1}$ Supplement 1 - inorganic minerals; Supplement 2 - inorganic minerals + amino acid chelated minerals + selenium yeast; Supplement 3 - inorganic minerals + mineral-amino acid complex $(\mathrm{Mn}+\mathrm{Zn}+\mathrm{Cu})$; Supplement 4 -inorganic minerals + metal chelate $(\mathrm{Mn}+\mathrm{Zn}+\mathrm{Cu})$-methionine hydroxy analogue.

Table 5 - Relative weight of digestive organs of Hy-Line White layers fed diets containing groups of minerals with different chemical characteristics, in the period of 94 to 109 weeks of age

\begin{tabular}{lccccc}
\hline Supplement $^{1}$ & Gizzard (\%) & Liver (\%) & Pancreas (\%) & Proventriculus (\%) & Intestines (\%) \\
\hline 1 & 1.13 & 2.58 & 0.20 & 0.34 & 3.10 \\
2 & 1.20 & 2.51 & 0.19 & 0.32 & 3.38 \\
3 & 1.09 & 2.40 & 0.17 & 0.30 & 3.19 \\
4 & 1.16 & 2.41 & 0.18 & 0.32 & 3.01 \\
Mean & 1.15 & 2.48 & 0.19 & 0.32 & 3.18 \\
CV (\%) & 14.06 & 13.98 & 21.81 & 15.97 & 9.77 \\
P-value & 0.7048 & 0.8158 & 0.6813 & 0.6138 & 0.2541 \\
\hline
\end{tabular}

$\mathrm{CV}$ - coefficient of variation.

1 Supplement 1 - inorganic minerals; Supplement 2 - inorganic minerals + amino acid chelated minerals + selenium yeast; Supplement 3 - inorganic minerals + mineral-amino acid complex $(\mathrm{Mn}+\mathrm{Zn}+\mathrm{Cu})$; Supplement 4 - inorganic minerals + metal chelate $(\mathrm{Mn}+\mathrm{Zn}+\mathrm{Cu})$-methionine hydroxy analogue. 
in the literature, which state that the larger bioavailability attributed to chelated minerals was not verified by the performance variables of the layers.

Manangi et al. (2015) worked with organic ( $\mathrm{Zn}, \mathrm{Cu}$, and Mn metal chelate $+\mathrm{MHA}$ ) and inorganic minerals in the production of commercial white-egg layers in the period of 24 to 80 weeks of age and observed that the feed intake, egg production, and egg mass variables were not influenced by supplementation in organic form. However, Sun et al. (2012) used Cu-MHA, Mn-MHA, and Zn-MHA supplementation in diets for brown-egg layers at 39 weeks of age and found different results for egg weight, which increased with organic supplementation.

Although the organic mineral sources had a higher bioavailability (Pessôa et al., 2012), promoting better results when consumed, in both trials (Tables 3 and 4), no improvements in terms of egg internal/external quality were seen with the supplements. A lack of effect of the chelated minerals on egg quality parameters was also reported by Swiatkiewicz and Koreleski (2008), Saldanha et al. (2009), and Geraldo et al. (2012).

However, Sun et al. (2012) worked with chelated minerals in the feeding of brown-egg layers (at 39 weeks of age) using a control diet with minerals in sulfated form, treatment 2 with supplementation of $10 \mathrm{mg} / \mathrm{kg}$ Cu-MHA, treatment 3 with supplementation of $20 \mathrm{mg} / \mathrm{kg} \mathrm{Zn-MHA}$, and treatment 4 with supplementation of $20 \mathrm{mg} / \mathrm{kg} \mathrm{Mn-MHA}$, and reported that shell thickness increased with $\mathrm{Zn}-\mathrm{MHA}$ and Mn-MHA. The positive effect of $\mathrm{Zn}-\mathrm{Cu}-\mathrm{Mn}-\mathrm{MHA}$ on eggshell thickness was also reported by Manangi et al. (2015).

According to Rutz et al. (2004), after absorption, organic minerals are readily transported to the body tissues, where they remain stored for longer periods than inorganic minerals. Selenium-methionine, for instance, is stored in tissues like the liver, pancreas, and kidney (Funari Junior, 2008) and may cause an increase in the relative weight of those organs when in excess, which was not observed in the current study (Table 5). Thus, we can infer that all mineral supplements provided the adequate levels of nutrients necessary for the good biometric quality of the organs observed.

Gheisari et al. (2011) worked with broilers fed diets containing organic and inorganic (sulfated and oxide forms) minerals in the following compositions: control - basal diet $\mathrm{Zn}, \mathrm{Mn}$, and $\mathrm{Cu}$ in oxide form; 100, 100, and $10 \mathrm{mg} / \mathrm{kg}$ respectively); diet 2 (140, 140, and $17 \mathrm{mg} / \mathrm{kg} \mathrm{Zn}, \mathrm{Mn}$, and Cu oxides associated with 40,40 , and $7 \mathrm{mg} / \mathrm{kg}$ thereof in organic form); diet $3(40,60$, and $8 \mathrm{mg} / \mathrm{kg}$ of $\mathrm{Zn}, \mathrm{Mn}$, and $\mathrm{Cu}$ in sulfated and oxide form); diet $4(40,40$, and $7 \mathrm{mg} / \mathrm{kg} \mathrm{Zn}, \mathrm{Mn}$, and $\mathrm{Cu}$, in amino acid complex form); diet 5 (40,40, and $7 \mathrm{mg} / \mathrm{kg} \mathrm{Zn,} \mathrm{Mn}$, and $\mathrm{Cu}$ in sulfated form); and diet 6 (60, 60 , and $10.5 \mathrm{mg} / \mathrm{kg}$ in amino acid complex form). According to the authors, the different mineral compositions of the diets did not influence the relative weight of the organs of birds (liver, spleen, and bursa).

Table 6 - Bone-related (tibia) variables of Hy-Line White layers fed diets containing groups of organic minerals with different chemical characteristics, in the period of 94 to 109 weeks of age

\begin{tabular}{lcccccc}
\hline Supplement $^{1}$ & $\begin{array}{c}\text { Weight } \\
(\mathrm{g})\end{array}$ & $\begin{array}{c}\text { Length } \\
(\mathrm{mm})\end{array}$ & $\begin{array}{c}\text { Seedor index } \\
(\mathrm{mg} / \mathrm{mm})\end{array}$ & $\begin{array}{c}\text { Resistance } \\
\left(\mathrm{kgf} / \mathrm{cm}^{2}\right)\end{array}$ & $\begin{array}{c}\text { Deformity } \\
(\mathrm{mm})\end{array}$ & $\begin{array}{c}\text { Mineral matter } \\
(\mathrm{g} / \mathrm{kg})\end{array}$ \\
\hline 1 & 7.07 & 115.32 & 61.32 & 10.74 & 2.33 & 48.61 \\
2 & 7.28 & 112.72 & 64.54 & 10.75 & 1.99 & 49.14 \\
3 & 7.70 & 114.56 & 67.07 & 10.25 & 2.03 & 50.53 \\
4 & 7.31 & 113.87 & 64.14 & 10.11 & 2.16 & 50.43 \\
Mean & 7.34 & 114.05 & 64.28 & 10.48 & 2.12 & 49.65 \\
CV (\%) & 10.07 & 2.12 & 8.67 & 0.1618 & 15.04 & 4.21 \\
P-value & 0.6116 & 0.3601 & 0.4651 & 0.8954 & 0.3483 & 0.3922 \\
\hline
\end{tabular}

$\mathrm{CV}$ - coefficient of variation.

${ }^{1}$ Supplement 1 - inorganic minerals; Supplement 2 - inorganic minerals + amino acid chelated minerals + selenium yeast; Supplement 3 - inorganic minerals + mineral-amino acid complex $(\mathrm{Mn}+\mathrm{Zn}+\mathrm{Cu})$; Supplement 4 - inorganic minerals + metal chelate $(\mathrm{Mn}+\mathrm{Zn}+\mathrm{Cu})$-methionine hydroxy analogue. 
Different results were reported by Netravathi et al. (2016), who worked with zinc-methionine and ironmethionine replacing inorganic minerals at the inclusion levels of 50,100, and $150 \%$ in diets for nakedneck hens and observed a higher relative weight of the gizzard with organic supplementation.

The bone is a conjunctive tissue formed by an organic matrix, where micro-minerals (copper, manganese, and zinc), as enzymatic co-factors, play a fundamental role in their synthesis and a mineral portion constituted of calcium phosphate (Nunes et al., 2013). Therefore, a balanced diet provides nutrients necessary for high-quality bone formation, resulting in more resistant bones. On this basis, it can be inferred that all mineral supplements adequately supplied the nutrients necessary for the good bone quality found (Table 6).

Results similar to those of this study for bone resistance were reported by Nunes et al. (2013), who worked with supplementation of increasing levels of $\mathrm{Cu}, \mathrm{Mn}, \mathrm{Zn}$, and Fe proteinates in diets for brownegg layers in the period of 30 to 70 weeks of age.

Gheisari et al. (2011) worked with inorganic and organic minerals ( $\mathrm{Zn}, \mathrm{Mn}$, and $\mathrm{Cu}$ ) alone or associated in the feeding of broilers and also did not find an influence of organic mineralization on the ash content of the tibiae of these birds.

\section{Conclusions}

Amino acid chelated minerals plus selenium yeast; mineral-amino acid complex; and metal chelate plus methionine hydroxy analogue can be used in diets of layers without affecting their performance, egg quality, digestive organs, or bone quality.

\section{Acknowledgments}

God; Tecnavic, for the donation of materials; Hy-Line do Brasil, for the donation of chicks; and Conselho Nacional de Desenvolvimento Científico e Tecnológico (CNPq), for the "scientific initiation" fellowship grant.

\section{References}

Abudabos, A. M. 2012. Effect of dietary phosphorus and calcium on performance of broilers from 3 to 7 weeks of age. Avian Biology Research 5:31-39. https://doi.org/10.3184/175815512X13267443354616

Alves, M. G. M.; Leite, S. C. B.; Goulart, C. C.; Silva, J. D. B. and Medeiros, F. M. 2015. Substituição dos minerais inorgânicos por orgânicos e duas granulometrias de calcário na dieta de poedeiras comerciais leves. Revista Agropecuária Técnica 36:128-135.

AAFCO - Association of American Feed Control Officials. 2000. Official Publication, Atlanta, GA.

Braz, N. M.; Freitas, E. R.; Bezerra, R. M.; Cruz, C. E. B.; Farias, N. N. P.; Silva, N. M.; Sá, N. L. and Xavier, R. P. S. 2011. Fibra na ração de crescimento e seus efeitos no desempenho de poedeiras nas fases de crescimento e postura. Revista Brasileira de Zootecnia 40:2744-2753. https://doi.org/10.1590/S1516-35982011001200019

Carvalho, L. S. S.; Vilela, D. R.; Fagundes, N. S.; Souza, Y. L. S. and Fernandes, E. A. 2016. Qualidade de ovos e desempenho produtivo de poedeiras em segundo ciclo de postura alimentadas com microminerais quelatados a aminoácidos. Ciência Animal Brasileira 17:491-500. https://doi.org/10.1590/1089-6891v17i420822

CONCEA - Conselho Nacional de Controle de Experimentação Animal. 2013. Normativas do CONCEA. Resolução Normativa n. 13, de 20 de setembro de 2013. Diretrizes da prática de eutanásia.

Funari Junior, P. 2008. Efeitos de diferentes fontes e níveis de selênio sobre o desempenho e a imunidade humoral de frangos de corte. Dissertação (M.Sc.). Universidade de São Paulo, Pirassununga.

Gheisari, A. A.; Sanei, A.; Samie, A.; Gheisari, M. M. and Toghyani, M. 2011. Effect of diets supplemented with different levels of manganese, zinc, and copper from their organic or inorganic sources on egg production and quality characteristics in laying hens. Biological Trace Element Research 142:557-571. https://doi.org/10.1007/s12011-010-8779-x

Geraldo, A.; Pinto, D. M.; Brito. J. A. G.; Bernardes, M. H.; Silva Jr., A. L.; Machado, L. C. 2012. Diferentes programas de suplementação de microminerais para poedeiras semipesadas em primeiro ciclo de produção. Arquivos de Pesquisa Animal 1:48-57.

R. Bras. Zootec., 48:e20170329, 2019 
Hy-Line do Brasil. 2016. Manual da linhagem: Poedeiras Comerciais Hy-Line White. Available at: <http://www.hyline. com/userdocs/pages/36_COM_POR.pdf>. Accessed on: May 31, 2016.

IBGE - Instituto Brasileiro de Geografia e Estatística. 2017. Indicadores IBGE: Estatística da Produção Pecuária Junho de 2017. Available at: <ftp://ftp.ibge.gov.br/Producao_Pecuaria/Fasciculo_Indicadores_IBGE/2017/abate-leite-couroovos_201701caderno.pdf>. Accessed on: Aug. 29, 2017.

Manangi, M. K.; Vazques-Añon, M.; Richards, J. D.; Carter, S. and Knigh, C. D. 2015. The impact of feeding supplemental chelated trace minerals on shell quality, tibia breaking strength, and immune response in laying hens. The Journal of Applied Poultry Research 24:316-326. https://doi.org/10.3382/japr/pfv029

Netravathi, T.; Jayanaik and Shivappa Nayaka, H. B. 2016. Effect of organic source mineral supplementation on the carcass characteristics and sensory quality of naked neck fowl. Journal of Meat Science and Technology 4:37-43.

Nunes, J. K.; Santos, V. L.; Rossi, P.; Anciuti, M. A.; Rutz, F.; Maier, J. C. and Silva, J. G. C. 2013. Qualidade de ovos e resistência óssea de poedeiras alimentadas com minerais orgânicos. Arquivo Brasileiro de Medicina Veterinária e Zootecnia 65:610-618. https://doi.org/10.1590/S0102-09352013000200043

Pacheco, B. H. C.; Trindade Neto, M. A.; Albuquerque, R. and Schammass, E. A. 2010. Níveis de lisina digestível e zinco quelato sobre os parâmetros produtivos de poedeiras marrons. Revista Brasileira de Zootecnia 39:2447-2452. https:// doi.org/10.1590/S1516-35982010001100018

Pessôa, G. B. S.; Tavernari, F. C.; Vieira, R. A. and Albino, L. F. T. 2012. Novos conceitos em nutrição de aves. Revista Brasileira de Saúde e Produção Animal 13:755-774. https://doi.org/10.1590/S1519-99402012000300015

Rostagno, H. S.; Albino, L. F. T.; Donzele, J. L.; Gomes, P. C.; Oliveira, R. F.; Lopes, D. C.; Ferreira, A. S. and Barreto, S. L. T. 2011. Tabelas brasileiras para aves e suínos: composição de alimentos e exigências nutricionais. 3.ed. UFV, Viçosa, MG. 252p.

Rutz, F.; Anciuti, M. A.; Rech, J. L. and Rossi, P. 2004. The impact of organic minerals on performance of poultry. XVI Annual Australian Poultry Science Symposium, Sydney, Australia. p.71-74.

Sakomura, N. K. and Rostagno, H. S. 2007. Métodos de pesquisa em nutrição em monogástricos. FUNEP, Jaboticabal. 283p.

Saldanha, E. S. P. B.; Garcia, E. A.; Pizzolante, C. C.; Faittarone, A. B. G.; Sechinato, A.; Molino, A. B. and Laganá, C. 2009. Effect of organic mineral supplementation on the egg quality of semi-heavy layers in their second cycle of lay. Brazilian Journal of Poultry Science 11:241-247. https://doi.org/10.1590/S1516-635X2009000400005

Saleh, A. A.; Ragab, M. M.; Ahmed, E. A. M.; Abudabos, A. M. and Ebeid, T. A. 2018. Effect of dietary zincmethionine supplementation on growth performance, nutrient utilization, antioxidative properties and immune response in broiler chickens under high ambient temperature. Journal of Applied Animal Research 46:820-827. https://doi.org/10.1080/09712119.2017.1407768

Seedor, J. G.; Quartuccio, H. A. and Thompson, D. D. 1991. The biophosphonate alendronate (MK-217) inhibits bone loss due to ovariectomy in rats. Journal of Bone and Mineral Research 6:339-346. https://doi.org/10.1002/jbmr.5650060405

Silva, D. J. and Queiroz, A. C. 2002. Análises de alimentos: métodos químicos e biológicos. UFV, Viçosa, MG. 235p.

Sun, Q.; Guo, Y.; Li, J.; Zhang, T. and Wen, J. 2012. Effects of methionine hydroxy analog chelated $\mathrm{Cu} / \mathrm{Mn} / \mathrm{Zn}$ on laying performance, egg quality, enzyme activity and mineral retention of laying hens. The Journal of Poultry Science 49:20-25. https://doi.org/10.2141/jpsa.011055

Swiatkiewicz, S. and Koreleski, J. 2008. The effect of zinc and manganese source in the diet for laying hens on eggshell and bones quality. Veterinarni Medicina 53:555-563. https://doi.org/10.17221/1966-VETMED 